\title{
First Costa Rican record of Pacific Golden-Plover (Pluvialis fulva, Gmelin, 1789) (Aves: Charadriidae)
}

\author{
Julio E. Sánchez ${ }^{1 \dagger}$, Johan Fernández Ramírez ${ }^{1,2}$ and César Sánchez ${ }^{1,3^{*}}$ \\ 1 Asociación de Ornitólogos Unidos de Costa Rica, Apartado 11695-1000, San José, Costa Rica. \\ 2 Universidad Estatal a Distancia Costa Rica, Escuela de Ciencias Naturales y Exactas. \\ 3 Louisiana State University, Department of Biological Sciences, and Museum of Natural Science, 119 Foster Hall, Baton Rouge, LA 70803, USA. \\ $\dagger$ Deceased. \\ * Corresponding author: E-mail: csanc15@lsu.edu
}

ABstract: Here we report on the first observation of Pacific Golden Plover in Central America, from Costa Rica. An individual in winter plumage was observed on salts ponds along with several other roosting waders

The Pacific Golden-Plover (Pluvialis fulva) has a breeding range extending from the Yamal Peninsula, the Koryak Mountains, and the Gulf of Anadyr in eastern Asia to extreme western Alaska (Hayman et al. 1991, Johnson and Connors 2010). Its wintering grounds span a large area across the Pacific and Indian Oceans, from Africa, India, the south Pacific, Hawaii to New Zealand and Australia (Hayman et al. 1991). In North America, some individuals regularly occur along the coasts of British Columbia, California, western Mexico, and the Revillagigedo Islands (Johnson and Connors 2010, A.O.U. 1998). Here we report the first record of Pacific Golden-Plover in Costa Rica and Central America.

On 30 September 2007, during the first Costa Rican Shorebird Annual Census, at La Ensenada Private Wildlife Refuge, prov. Puntarenas, Costa Rica $\left(10^{\circ} 08^{\prime} 83^{\prime \prime} \mathrm{N}\right.$, $85^{\circ} 03^{\prime} 04^{\prime \prime} \mathrm{W}$ ), we observed one adult individual in winter plumage (Figure 1). The bird was observed from 08:30 to $09: 00 \mathrm{~h}$ roosting on a salt pond. The individual was distinguished from American Golden-Plover by its brighter plumage, slimmer body, a prominent ear-spot, yellowish face, and shorter primary wing projections in comparison to the tail length (Figure 1). At the same salt pond there were several other roosting waders, including several Black-bellied Plovers (Pluvialis squatarola), Whimbrel (Numenius phaeopus), Willet (Tringa semipalmata), Ruddy Turnstone (Arenaria interpres), Short-billed Dowitcher (Limnodromus griseus), and Black-necked Stilt (Himantopus mexicanus).

Along the Americas, the species is known to wonder to such southern latitudes as Clipperton Island (Stager 1964; Howell et al. 1993) and even to the Atlantic, i.e. Bermuda and Barbados (Crossley 2002). There are sight records from Chile (Hayman et al. 1991), Ecuadorian coast (Ridgely and Greenfield 2001), and the Galapagos Islands (Haase 2011), but these are not supported by substantiating evidence (Remsen et al. 2013). The lack of observations prior to or subsequent to our record, despite the large number of survey hours in the area, suggests that this was an isolated occurrence. The Golfo Nicoya in Costa Rica, including the surrounding mangroves, mud beaches, salt ponds, and shrimp farms, is the most important stopover and wintering area for shorebirds in Costa Rica (Barrantes and Sánchez 2003; Barrantes and Pereira 2011). This makes this area as an ideal place for vagrants and common individuals of shorebirds during the migration periods.

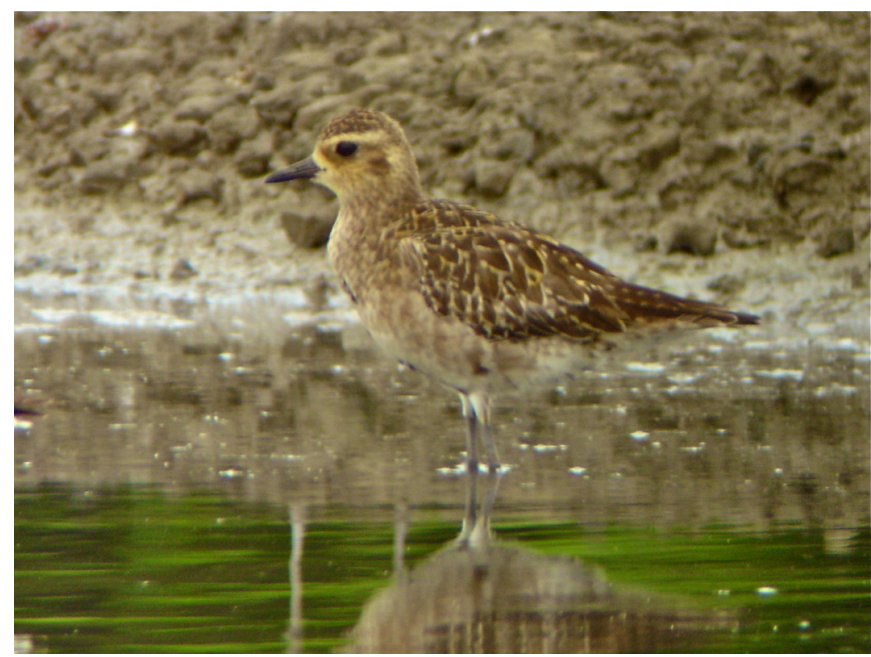

FigurE 1. Pluvialis fulva photographed 30 September 2007, at La Ensenada Private Wildlife Refuge, prov. Puntarenas, Costa Rica. Identification confirmed by Matt Brady, Steven W. Cardiff, Donna L. Dittman, and Ryan Terrill. Photo: Johan Fernández Ramírez.

ACKNOWLeDgments: We thank Luis Sandoval, J. V. Remsen, and J. J. Withrow for commenting on a previous draft. To Matt Brady, Steven W. Cardiff, Donna L. Dittman, and Ryan Terrill for confirming the species identification. For supporting the National Costa Rican Shorebird Census we thank to Swarovski Optik, Cotinga Tours, and Finca Naturales, also to La Ensenada Lodge by allowing us to conduct the censuses in their property.

\section{LITERATURE CITED}

American Ornithologists' Union. 1998. Check-list of North American birds. Seventh ed. Washington DC: American Ornithologists' Union. 829 pp. Barrantes, G. and A. Pereira. 2011. Manglares y franja costera del Golfo de Nicoya (CR004); pp. 61-65, in: L.Sandoval and C. Sánchez (ed.). Áreas Importantes para la Conservación de las Aves de Costa Rica. San José: Unión de Ornitólogos de Costa Rica.

Barrantes, G. and J.E. Sánchez. 2003. Geographical distribution, ecology, and conservation status of Costa Rican dry forest avifauna; pp. 147-159, in: F. Gordon, A. Mata, and S. B. Vinson (ed.). Biodiversity conservation in Costa Rica: learning the lesson in a seasonal dry forest. California: University of California Press.

Crossley, R. 2002. New Jersey's First Pacific Golden-Plover. Records of New Jersey Birds 28: 57-60.

Johnson, O. W. and P. G. Connors. 2010. Pacific Golden-Plover (Pluvialis 
fulva); in: A. Poole (ed.). The Birds of North America Online. Ithaca: Cornell Lab of Ornithology. Accessible at http://bna.birds.cornell. edu/bna/species/201doi:10.2173/bna.201. Captured on 23 February 2013.

Haase, B. J. M. 2011. Aves marinas de Ecuador continental y acuáticas de las piscinas artificiales de Ecuasal. Guayaquil: Aves \& Conservación/ BirdLife International/Ecuasal. 170 pp.

Hayman, P., J. Marchant and T. Prater. 1991. Shorebirds: An Identification guide. Princeton: Houghton Mifflin Harcourt. 412 pp.

Howell, S.N.G., P. Pyle, L.B. Spear, and R.L. Pitman. 1993. North American migrant birds on Clipperton Atoll. Western Birds 24: 73-80.

Remsen, J. V., Jr., C. D. Cadena, A. Jaramillo, M. Nores, J. F. Pacheco, J. Pérez-Emán, M. B. Robbins, F. G. Stiles, D. F. Stotz, and K. J. Zimmer.
2013. A classification of the bird species of South America. American Ornithologists' Union. Accessible at http://www.museum.lsu. edu/ Remsen/SACCBaseline.html. Captured on 10 April 2013.

Ridgely, R.S. and P. Greenfield. 2001. The Birds of Ecuador: Status, Distribution, and Taxonomy. Ithaca: Cornell University Press. 880 pp. Stager, K. E. 1964. The Birds of Clipperton Island, Eastern Pacific. Condor 66: 357-371.

RECEIVED: April 2013

ACCEPTED: November 2013

PuBlished ONLINE: February 2014

EDITORIAL RESPONSIBILITY: Vítor de Q. Piacentini 